\title{
Penerapan Data Mining Untuk Memprediksi Kompetensi Siswa Menggunakan Metode Decission Tree ( Studi Kasus SMK Multicomp Depok )
}

\author{
Ade Irma Rizmayanti ${ }^{1}$, Nadiyah Hidayati ${ }^{2}$, Fitra Septia Nugraha ${ }^{3}$, Windu Gata ${ }^{4}$ \\ 1,2,3,4 STMIK NUSA MANDIRI \\ e-mail:114002347@nusamandiri.ac.id,214002368@nusamandiri.ac.id, \\ 3fitra.fig@nusamandiri.ac.id, ${ }^{4}$ windu@nusamandiri.ac.id
}

\begin{abstract}
Penelitian ini membahas tentang Penerapan data mining untuk mempredikasi kompetensi siswa menggunakan metode decission tree. Dalam penelitian ini menerapkan data mining untuk memprediksi kompetensi siswa menggunakan metode decision tree. Penelitian ini dilakukan untuk memprediksi hasil belajar siswa berdasarkan data nilai raport semester 1, semester 2 semester 3 dan semester 4. Data kemudian dikelola menggunakan Rapid Miner untuk mempermudah memprediksi kompetensi siswa .Penelitian dilakukan diSMK Multicomp yang mempunya 3 jurusan yaitu Akomodasi Perhoten, Bisnis Daring dan Pemsaran dan Multimedia. Penelitian menggunakan data dari siswa setiap jurusan tersebut meliputi kelas $X$ sampai kelas $X I$. Penerapan data mining digunakan untuk memprediksi kompetensi siswa dengan menggunakan decision tree dan algoritma $C 45$ sebagai pendukung sekaligus perbandingan untuk mengetahui kompetensi siswa SMK Multicomp Depok berdasarkan kedua metode tersebut. Metode ini mampu mengukur kemampuan siswa secara tepat dan mampu memberikan pemahaman pada tingkat tertentu sesuai kebutuhan Dunia pendidikan diindonesia memiliki pola dan strategi pembelajaran berbasis pada kemampuan nalar siswa.Siswa diharapkan mampu menganalisis sebuah permasalahan dengan baik dan menemukan solusi yang tepat.Pada kenyataannya pendekatan kemampuan nalar siswa tidak diiringi oleh sistem pendidikan atau kurikulum yang memadai.Kompetensi guru yang tidak merata diberbagai sekolah dan pemerintah dirasakan sangat kurang dalam mewujudkan sistem pendidikan berbasis nalar.
\end{abstract}

Kata Kunci: data mining,pohon keputusan

\begin{abstract}
Abstract- This study discusses the application of data mining to predict student competencies using the decision tree method. In this study applying data mining to predict student competency using the decision tree method. This research was conducted to predict student learning outcomes based on report card grades semester 1, semester 2 semester 3 and semester 4 . Data were then managed using Rapid Miner to facilitate predicting student competencies. The study was conducted at Multicomp SMK which has 3 majors namely Hospitality Accommodation, Online Business and Marketing and Multimedia. Research using data from students in each department includes class $X$ and class XI. The application of data mining is used to predict student competencies by using a decision tree and C 4.5 algorithm as a support as well as a comparison to determine the competency of students of Multicomp Depok Vocational School based on both methods. This method is able to measure the ability of students appropriately and be able to provide an understanding at a certain level according to the needs of Indonesian education has a pattern and learning strategy based on students' reasoning abilities. Students are expected to be able to analyze a problem well and find the right solution. students are not accompanied by an
\end{abstract}


adequate education system or curriculum. Teacher competencies that are not evenly distributed in various schools and governments are felt to be very lacking in realizing reasoning based education systems.

Keywords: data mining,decision tree

\section{Pendahuluan}

Berdasarkan undang undang Republik Indonesia Nomor 20 Tahun 2003 Tentang Sistem Pendidikan Nasional disebutkan bahwa Sekolah Menengah Kejuruan (SMK) adalah salah satu bentuk satua pendidikanh formal yang menyelenggarakan pendidikan kejuruan pada jenjang pendidikan menengah sebagai lanjutan dari SMP/MTs atau bentuk lain yang sederajat atau lanjutan dari hasil belajar yang diakui sama/setara SMP/MTs.(UU Nomor 20 Tahun 2013,

Pasal 18 ayat [3]. Pendidikan kejuruan merupakan pendidikan menengah yang mempersiapkan peserta didik terutama untuk bekerja dalam bidang tertentu.(UU Nomor 20 Tahun 2013, Penjelasan Pasal 15)

Tujuan diselenggarakan sekolah kejuruan adalah untuk membekali lulusan dengan kompetensi yang berguna bagi diri sendiri, masa depan dan kehidupan bermasyarakat.Tujuan ini akan lebih terarah jika kurikulum yang digunakan tepat dan dilaksanakan dengan baik. Untuk meningkatkan kualitas lulusan SMK dibutuhkan kerjasama yang baik antara pemerintah,sekolah, kemitraan dengan dunia industri, kompetensi guru, orangtua dan siswa itu sendiri.Semua elemen tersebut saling berpengaruh baik secara langsung ataupun tidak langsung yang nantinya akan berpengaruh juga pada kualitas pendidikan sekolah tersebut.

Siswa merupakan salah satu elemen sekolah yang perlu diperhatikan dalam dunia pendidikan karena pada sebuah sekolah terutama sekolah swasta siswa sangat berpengaruh pada kemajuan sekolah tersebut. Siswa merupakan salah satu elemen sekolah yang perlu diperhatikan dalam dunia pendidikan karena pada sebuah sekolah terutama sekolah swasta siswa sangat berpengaruh pada kemajuan sekolah tersebut.Prediksi kompetensi siswa dilakukan untuk mengantisipasi dan pengambilan keputusan pihak sekolah terhadap siswa tersebut kompeten atau tidak untuk melanjutkan ke proses UKK (Uji Kompetensi Siswa)

Data Mining adalah proses yang menggunakan teknik statistik, matematika, kecerdasan buatan, machine learning untuk mengekstraksi dan mengidentifikasi informasi yang bermanfaat dan pengetahuan yang terkait dari berbagai database besar (Turban dkk. 2005). Terdapat beberapa istilah lain yang memiliki makna sama dengan data mining, yaitu Knowledge discovery in databases (KDD), ekstraksi pengetahuan (knowledge extraction), Analisa data/pola (data/pattern analysis), kecerdasan bisnis (business intelligence) dan data archaeology dan data dredging (Larose, 2005).

Prediction atau fungsi prediksi merupakan salah satu fungsi data mining. Maksudnya yaitu dari proses nanti akan menemukan pola tertentu dari suatu data. Pola tersebut dapat diketahui dari variabelvariabel yang ada pada data. Pola yang didapat bisa digunakan untuk memprediksi variabel lain yang belum diketahui nilai ataupun jenisnya. Karena itulah fungsi satu ini dikatakan sebagai fungsi prediksi. Nantinya bisa digunakan untuk memprediksi variabel tertentu yang tidak ada dalam suatu data. Hal ini tentunya memudahkan dan menguntungkan bagi mereka pemilik kepentingan yang memerlukan prediksi akurat untuk membuat hal penting tersebut menjadi lebih baik.

Pengertian kompetensi adalah suatu kemampuan atau kecakapan yang dimiliki oleh seseorang dalam melaksanakan suatu pekerjaan atau tugas di bidang tertentu, sesuai dengan jabatan yang disandangnya. Pendapat lain mengatakan arti kompentesi adalah suatu keterampilan, pengetahuan, sikap dasar, dan nilai yang terdapat dalam diri seseorang yang tercermin dari kemampuan berpikir dan bertindak secara konsisten. Dengan kata lain, kompetensi tidak hanya tentang 
pengetahuan atau kemampuan seseorang, namun kemauan melakukan apa yang diketahui sehingga menghasilkan manfaat. Secara etimologis kata "kompetensi" diadaptasi dari bahasa Inggris, yaitu "competence" atau "competency" yang artinya kecakapan, kemampuan, dan wewenang. Sehingga pengertian kompetensi adalah gabungan antara pengetahuan, keterampilan dan atribut kepribadian seseorang sehingga meningkatkan kinerjanya dan memberikan kontribusi bagi keberhasilan organisasinya.

Decission Tree adalah suatu metode klasifikasi yang menggunakan struktur pohon dimana setiap node merepresentasikan atribut dan cabangnya mempresentasikan nilai dari atribut sedangkan daunnya digunakan untuk mempresentasikan kelas.Node teratas dari decision tree ini disebut root,Breiman et al (1984) menyatakan bahwa metode ini merupakan metode yang popular untuk digunakan karena hasil dari model yang terbentuk mudah untuk dipahami.Dinamai pohon keputusan karena aturan yang dibentuk mirip dengan pohon.Pohon dibentuk dari proses penyortiran rekursif biner dalam kelompok data,sehingga nilai variable respons disetiap kelompok.Konsep dari pohon keputusan adalah mengubah data menjadi decision tree dan aturan keputusan.Manfaat utama dari menggunakan pohon keputusan adalah kemampuan menyederhanakan proses pengambilan keputusan sehingga pembuat keputusan dapat menafsirkan solusi untuk masalah.

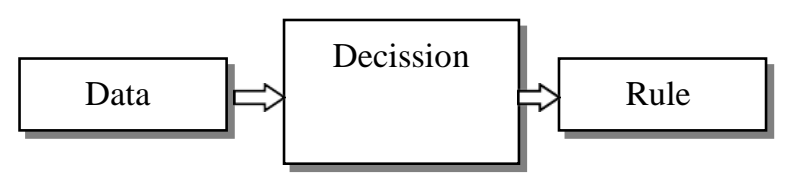

\section{Gambar Konsep Decision Tree}

Nama lain dari decision tree adalah CART (Classification and Regression Tree). Metode ini merupakan kombinasi dari dua spesies pohon, pohon klasifikasi dan pohon regresi. Demi kesederhanaan. Tahap Pembentukan Decision Tree:

1. Konstruksi pohon diawali dengan pembentukan akar (terletak paling atas). Kemudian data dipecah menggunakan atribut yang cocok untuk digunakan sebagai lembar.

2. Pemangkasan pohon (tree pruning) yaitu mengidentifikasikan dan membuang cabang yang tidak diperlukan pada pohon yang telah terbentuk. Ini karena pohon keputusan yang dibuat bisa besar sehingga dapat disederhanakan dengan pemangkasan berdasarkan nilai kepercayaan (level kepercayaan). Penanaman pohon dilakukan selain mengurangi ukuran pohon untuk juga mengurangi tingkat kesalahan prediksi dalam kasus-kasus baru dari hasil pemecahan split dan larutan.

$$
\text { 3. Pembentukan aturan }
$$

keputusan yaitu membuat aturan keputusan dari pohon yang telah dibentuk. Aturannya bisa dalam bentuk if-then yang diturunkan dari pohon keputusan dengan menelusuri dari akar ke daun. Untuk setiap node dan cabang, jika ditentukan, maka nilai sheet dimasukkan. Setelah semua aturan dibuat, aturan dapat disederhanakan atau digabungkan.

Pohon keputusan adalah model klasifikasi paling populer karena dapat dengan mudah ditafsirkan oleh manusia. Banyak algoritma dapat digunakan untuk membangun pohon keputusan seperti ID3, C4.5, CART, dan GUIDE.

\section{Manfaat Decision tree}

Decision tree juga berguna untuk mengeksplorasi data, menemukan hubungan tersembunyi antara sejumlah calon variabel input dengan sebuah variabel target. Pohon keputusan menggabungkan eksplorasi data dan pemodelan yang menjadikannya langkah pertama yang sangat baik dalam proses pemodelan bahkan ketika digunakan sebagai model akhir untuk beberapa teknik lainnya.Dalam beberapa aplikasi, akurasi dari sebuah klasifikasi atau prediksi adalah satu-satunya hal yang ditonjolkan dalam metode ini, Misalnya perusahaan surat langsung membuat model yang akurat untuk memprediksi anggota mana yang berpotensi merespons permintaan terlepas dari bagaimana atau mengapa model itu berfungsi.

Kelebihan lain dari metode ini adalah mampu mengeliminasi perhitungan atau data-data yang kiranya tidak diperlukan. Karena sampel yang ada 
biasanya hanya diuji berdasarkan kriteria atau kelas tertentu. Meski memiliki banyak kelebihan, namun bukan berarti metode ini tidak memiliki kekurangan. Pohon keputusan ini mungkin tumpang tindih, terutama jika kelas dan kriteria yang digunakan sangat sering dapat meningkatkan waktu pengambilan keputusan sesuai dengan kapasitas memori yang diperlukan.

\section{Penerapan Decision tree}

Decision tree atau pohon keputusan adalah alat pendukung keputusan yang menggunakan model keputusan yang berbentuk seperti pohon. Pohon keputusan menggambarkan berbagai alternatif yang mungkin untuk mengatasi suatu masalah dan ada juga faktor-faktor potensial yang dapat memengaruhi alternatif tersebut bersama dengan perkiraan akhirnya ketika suatu alternatif dipilih. Pohon keputusan adalah metode yang dapat digunakan untuk menampilkan algoritma yang hanya berisi pernyataan kontrol bersyarat.

Penggunaan Decision tree ini umunya dalam riset operasi, khususnya dalam analisis keputusan. Tujuan menggunakan pohon keputusan adalah untuk mengidentifikasi strategi yang paling mungkin untuk mencapai tujuan dan merupakan alat yang populer dalam pembelajaran mesin.

Decision tree merupakan struktur seperti bagan alur dimana setiap simpul internal mewakili kemungkinan yang ada pada atribut, masing-masing cabang mewakili hasil dari kemungkinan itu dan setiap simpul daun mewakili nama kelas (keputusan dibuat setelah semua atribut telah dihitung). Jalur dari root ke leaf mewakili aturan klasifikasi. Dalam analisis keputusan, decision tree dan diagram yang terkait dengan itu digunakan sebagai alat pendukung keputusan visual dan analitis, dimana akan dihitungnya nilai atau utilitas yang diharapkan dari alternatif yang ada.

\section{Metode Penelitian}

Metode penelitian yang digunakan pada penelitian ini terdiri dari :

1. Rancangan Penelitian.

Metode yang digunakan dalam penelitian ini adalah metode deskriptif kualitatif, Metode deskriptif dapat diartikan sebagai prosedur pemecahan masalah yang diselidiki dengan menggambarkan keadaan subjek atau objek dalam penelitian dapat berupa orang, lembaga, masyarakat dan yang lainnya yang pada saat sekarang berdasarkan fakta-fakta yang tampak atau apa adanya. Menurut Nazir (1988: 63) dalam Buku Contoh Metode Penelitian, metode deskriptif merupakan suatu metode dalam meneliti status sekelompok manusia, suatu objek, suatu set kondisi, suatu sistem pemikiran ataupun suatu kelas peristiwa pada masa sekarang. Tujuan dari penelitian deskriptif ini adalah untuk membuat deskripsi, gambaran, atau lukisan secara sistematis, faktual dan akurat mengenai fakta-fakta, sifatsifat serta hubungan antar fenomena yang diselidiki. Menurut Sugiyono (2005: 21) menyatakan bahwa metode deskriptif adalah suatu metode yang digunakan untuk menggambarkan atau menganalisis suatu hasil penelitian tetapi tidak digunakan untuk membuat kesimpulan yang lebih luas. Menurut Whitney (1960: 160) metode deskriptif adalah pencarian fakta dengan interpretasi yang tepat. Dapat dikatakan bahwa penelitian deskriptif merupakan penelitian yang berusaha mendeskripsikan suatu gejala, peristiwa yang terjadi pada saat sekarang atau masalah actual.

2. Sumber Data

Sumber data dari penelitian ini berasal dari ledger siswa siswi tahun angkatan 2017-2018 dari kelas X sampai kelas XI semester 1 sampai dengan semester 4 pada salah satu SMK swasta yang berlokasi diKalimulya Depok yaitu SMK Multicomp.SMK Multicomp didirikan pada tahun 2002, dan didirikan oleh Almarhumah Dra.Hj.Nurul Qomariah yang sebelumnya juga selaku kepala sekolah SMK Multicomp dan sepeninggal beliau SMK Multicomp dipimpin oleh Ibu Sulastri Spd selaku kepala sekolah. SMK Multicom dibangun dengan berlantai tiga pada tiap baris gedungnya dan terus membangun infrastruktur ruang belajar dan sarana fasilitas lainnya. SMK Multicomp mempunyai tiga bidang keahlian yaitu Bisnis Daring dan Pemasaran, Akomodasi Perhotelan, Multimedia. 
Data kriteria yang digunakan sebagai parameter untuk mengukur kriteria penilaian kompetensi adalah raport siswa dari kelas $X$ semester 1 dan 2, raport siswa kelas XI semester 3 dan 4 . Data bentuk yang akan dijadikan kriteria untuk penelitian adalah Jenis Kelamin, Jurusan, Kelas, Mata Pelajaran, Nilai, Status Kompeten atau tidak Kompeten.

\section{Teknik Pengumpulan data}

Teknik Pengumpulan Data yang dilakukan untuk penelitian ini adalah sebagai berikut :

1. Wawancara yaitu merupakan salah satu bentuk teknik pengumpulan data yang banyak digunakan dalam bentuk deskkriptif kualitatif dan deskriptif kuantitatif. Wawancara dilaksanakan secara lisan dalam pertemuan tatap muka individual atau kelompok. Dalam hal ini teknik wawancra dibedakan menjadi dua yaitu teknik wawancara terstruktur dan teknik wawancara tidak terstruktur.

2. Observasi yaitu merupakan suatu teknik atau cara pengumpulan data dengan jalan mengadakan pengamatan terhadap kegiatan yang sedang berlangsung.

d. Analisis Data Penelitian

Data yang digunakan untuk mendukung dalam melakukan penelitian ini adalah data primer dan juga data sekunder yaitu :

a) Data Primer adalah data yang diperoleh langsung dari objek data Seperti jenis kelamin,jurusan ,kelas,mata pelajaran,nilai,satus kompeten atau tidak kompeten.

b) Data Sekunder adalah data yang nanti akan diperoleh dengan membaca dan mempelajari referensi yang berkaitan dengan penelitian yang dilakukan.

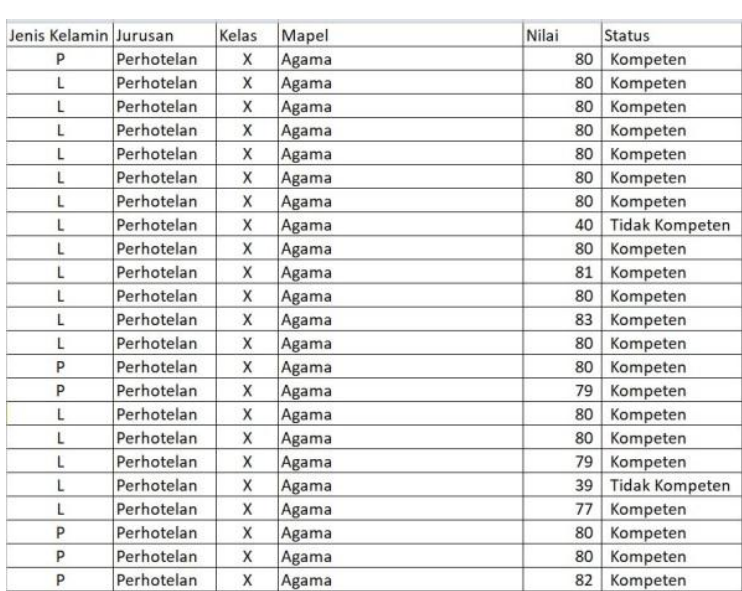

Data Siswa Awal

\section{Hasil dan Pembahasan}

Hasil dari penelitian yang sudah dilakukan adalah sebagai berikut pertama tama dilakukan import data excel yang ada di Rapid miner dengan hasil seperti dibawah ini

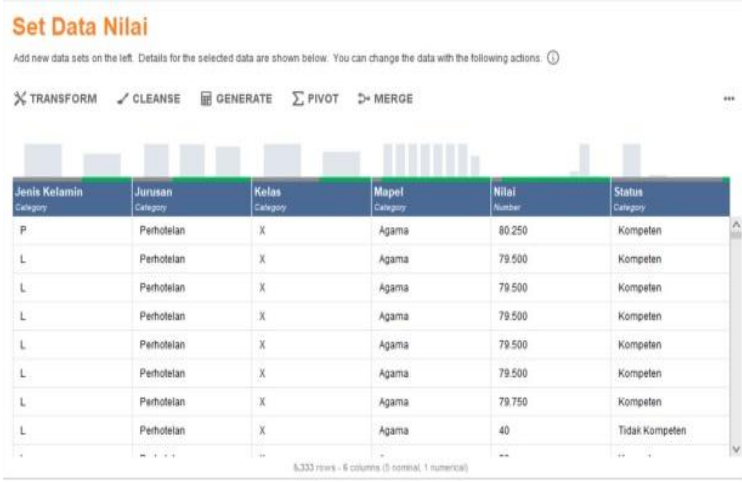

Gambar import data

Setelah melakukan import data $d r$ excel tahapan selanjutnya adalah kita simpan data tersebut pada local repository dari rapid miner. 


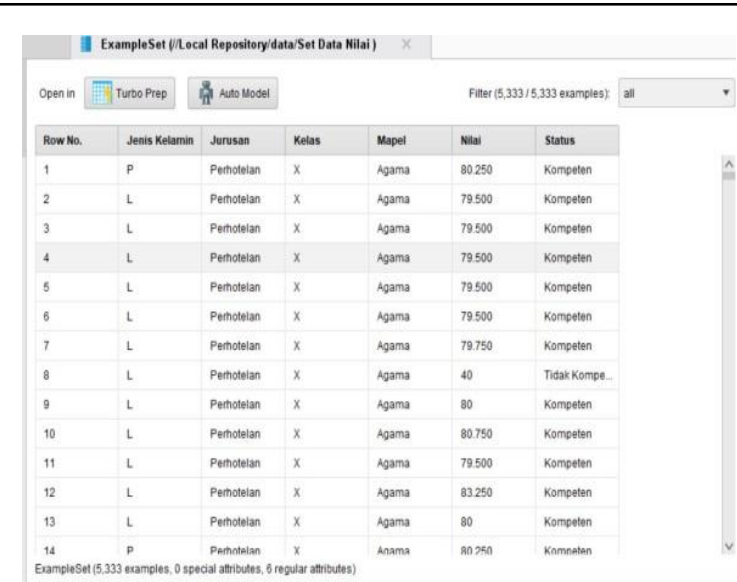

Gambar Local Repositort

Berikut merupakan hasil dari import data yg sudah tersimpan di data local Rapid Miner

\section{Set Data Nilai}

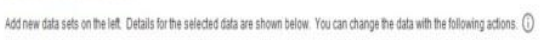

X TRANSORM /CLEANSE PGenerate ¿PNOT DOMERGE

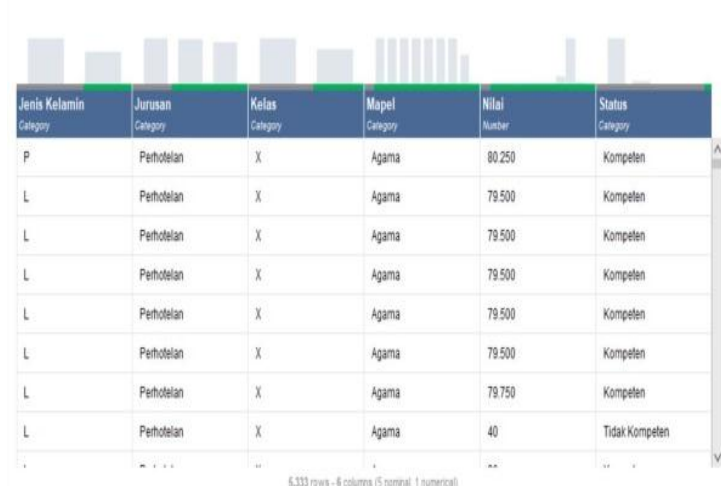

\section{Gambar Set Data}

Selanjutnya data akan ditampilkan masing masing summary seperti berikut ini

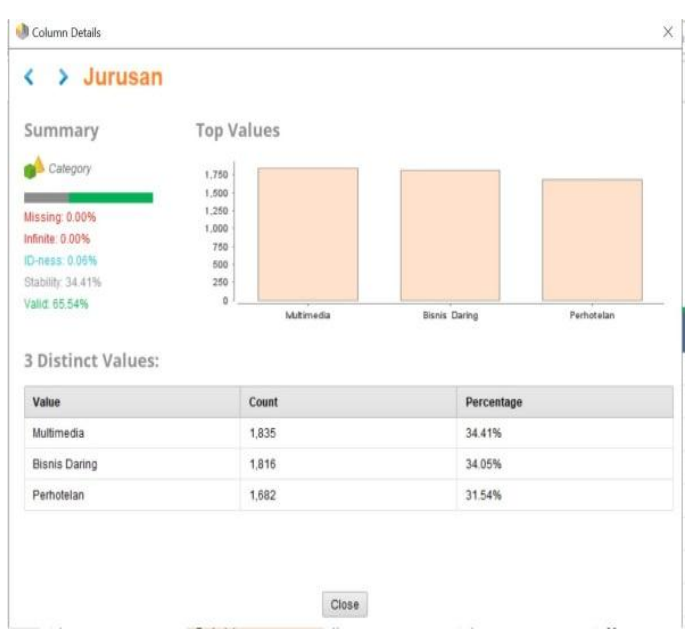

Gambar Detail Data Jurusan

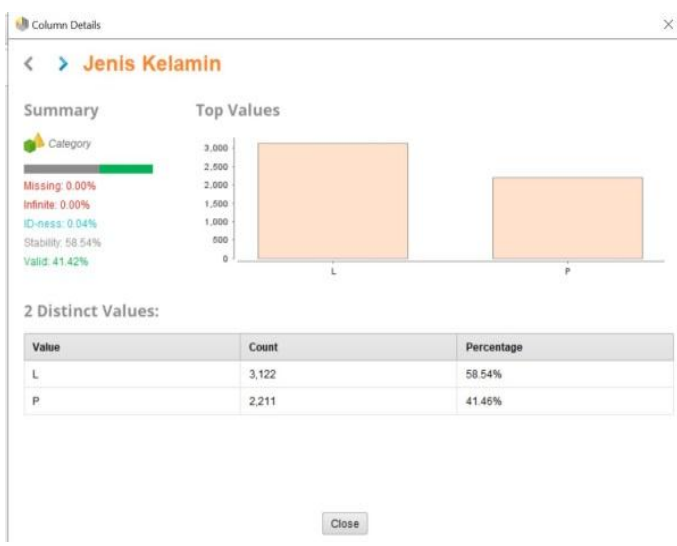

Gambar Detail Data Jenis Kelamin

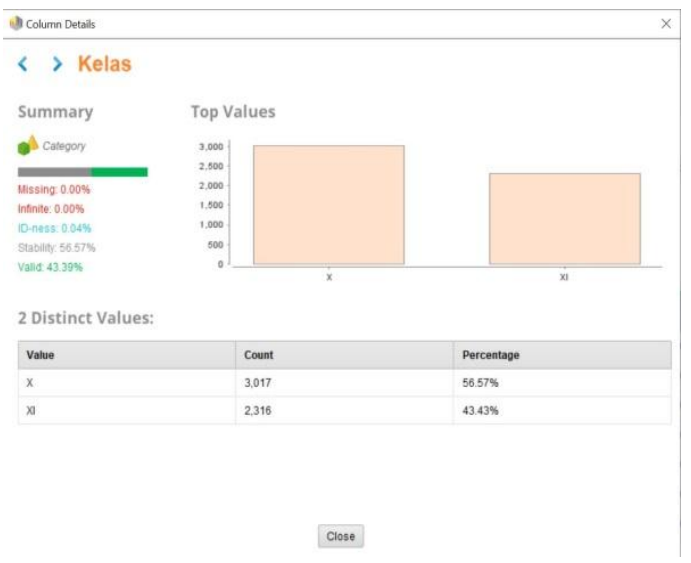

Gambar Detail Data Kelas 


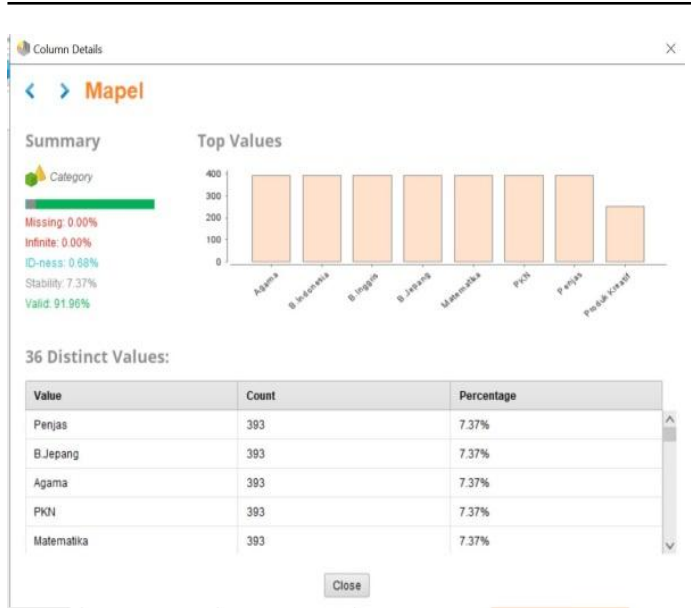

Gambar Detail Data Mata Pelajaran

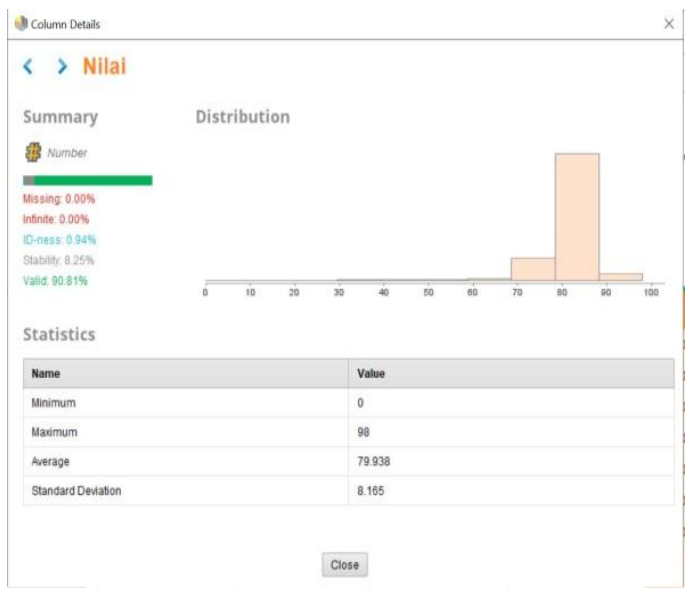

Gambar Detail Data Nilai

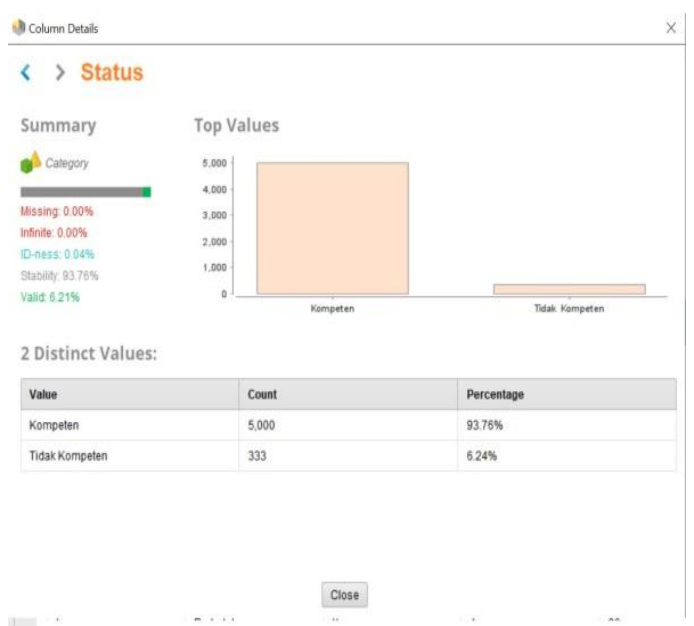

Gambar Detail Data Status Siswa
Data nilai setelah summary akan ditampilkan siswa yang kompetensi dan tidak kompetensi berbentuk grafik seperti berikut ini

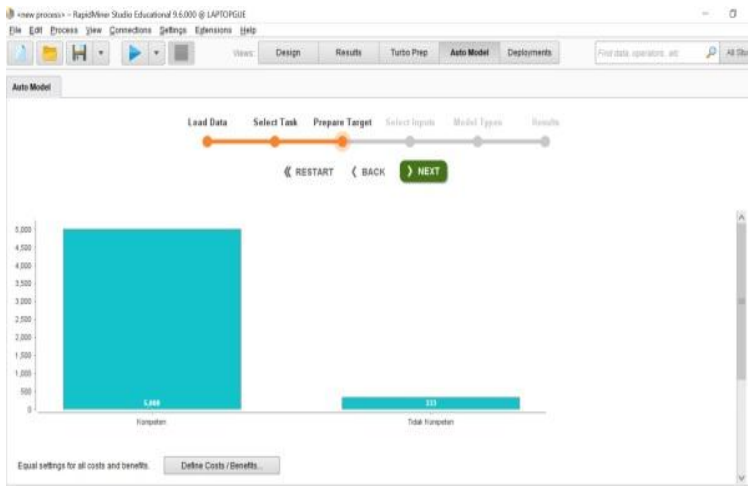

Gambar Grafik Kompetensi Siswa

\section{Kelulusan siswa akan ditampilkan} dengan lift chart seperti berikut ini

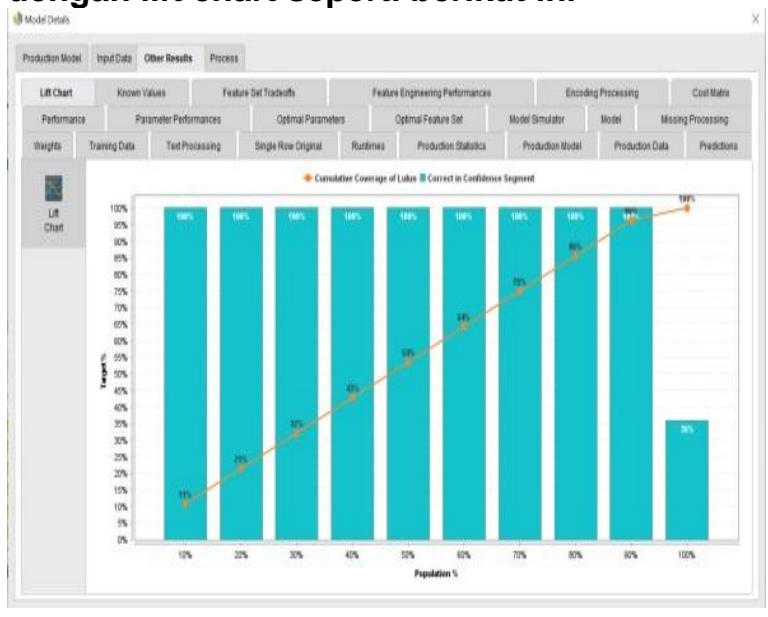

\section{Gambar lift chart kelulusan}

Berikut adalah hasil akhir dari penelitian ditampilkan decision tree dari prediksi kompetensi siswa 


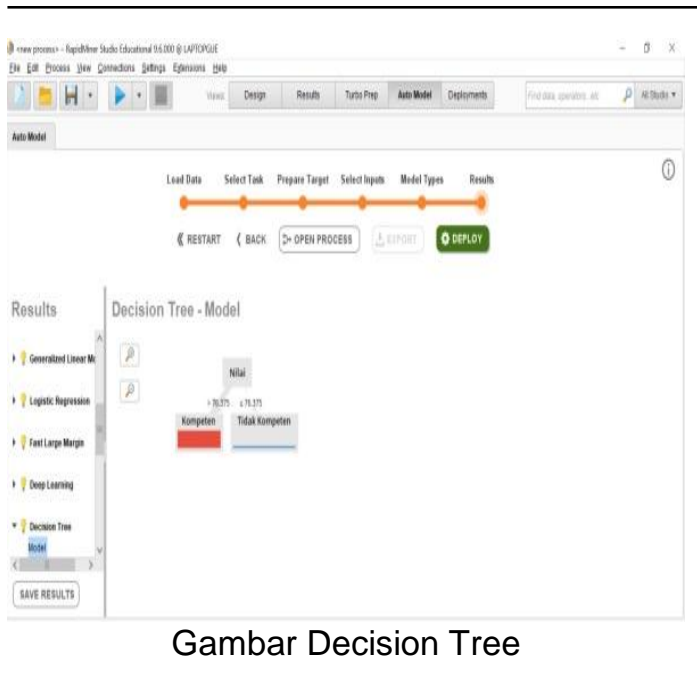

\section{Kesimpulan}

Dengan data mining menggunakan metode decision tree dapat membuat prediksi untuk kompetensi siswa yang berguna bagi pihak sekolah sebagai bahan evaluasi guru mata pelajaran dan pihak sekolah untuk bisa memantau siswa yang kompeten dan tidak kompeten untuk melanjutkan ke proses Uji Kompetensi Keahlian.

\section{Referensi}

Denis Aprilia C, Donny Aji Baskoro, Lia Ambarwati, I Wayan Simri Wicaksana. (2013). Belajar Data Mining Dengan Rapid Miner. Gramedia Pustaka Utama, 45

Dita Merawati, R. (2019). Penerapan Data Mining Penentu Minat Dan Bakat Siswa Smk Dengan Metode C4 . 5. Jurnal Algor, 1(1), 28-37.

Sapta, A., Mustika, S. L. F., \& Sembiring Ardiansyah Muhammad. (2018). Analisa Kinerja Algoritma C.45 Dalam Memprediksi Hasil Belajar. Journal of Science and Social Research, 1(February), 73-79. Retrieved from http://jurnal.goretanpena.com/index .php/JSSR

Kurniawan, A. (2019). Memprediksi Kelulusan Uji Kompetensi Smk Teknik Komputer Dan Jaringan ( Tkj ) ( Study Kasus: Smk Pembangunan Daerah Lubuk Pakam ). Majalah IImiah INTI, 14(September).
Pambudi, R. H., Setiawan, B. D., \& Indriati. (2018). Penerapan Algoritma C4 . 5 Untuk Memprediksi Nilai Kelulusan Siswa Sekolah Menengah Berdasarkan Faktor Eksternal. Jurnal Pengembangan Teknologi Informasi Dan Ilmu Komputer, 2(7), 2637-2643. Retrieved from http://jptiik.ub.ac.id5

Zazkya Fitri Sylvarez, Tri Indra Wijaksana, S.Sos., M. S. (2016). Penerapan Data Mining Untuk Prediksi Tingkat Kompetensi Karyawan Pada Pt. Hankook Tire Indonesia Dengan Metode Algoritma C4.5. EProceeding of Management ISSN: 2355-9357, 3(1 April), 477-484. https://doi.org/10.1037/cou0000103

Muchlisin Riadi(21 September 2017). Pengertian fungsi proses dan tahapan Data Mining. https://www.kajianpustaka.com/201 7/09/data-mining.html

Susanto, H., \& Sudiyatno, S. (2014). Data mining untuk memprediksi prestasi siswa berdasarkan sosial ekonomi, motivasi, kedisiplinan dan prestasi masa lalu. Jurnal Pendidikan Vokasi, $\quad 4(2), \quad 222-231$. https://doi.org/10.21831/ipv.v4i2.25 $\underline{47}$

Novianti, B., Rismawan, T., \& Bahri, S. (2016). Implementasi Data Mining Dengan Algoritma C4.5 Untuk Penjurusan Siswa (Studi Kasus: Sma Negeri 1 Pontianak). Jurnal Coding, Sistem Komputer Untan, 04(3), 75-84.

Sugianto, C. A., \& Pujiyanita, N. S. (2019). Optimalisasi Algoritma C4.5 Menggunakan Algoritma Genetika Untuk Prediksi Kelulusan Siswa Smkn 2 Cimahi. Infotekmesin, 10(2), 9-14.

https://doi.org/10.35970/infotekmesi $\underline{\text { n.v10i2.35 }}$

Jaman, J. H., \& Astuti, N. I. P. (2018). Penerapan Algoritma C4.5 untuk Penentuan Penerima Beasiswa (Studi Kasus: SDN Karawang Kulon III). Techno Xplore: Jurnal IImu 
Komputer Dan Teknologi Informasi, 3(1), 25-29. https://doi.org/10.36805/technoxplo re.v3i1.796

Muhamad, M., Windarto, A. P., \& Suhada, S. (2019). Penerapan Algoritma C4.5 Pada Klasifikasi Potensi Siswa Drop Out. KOMIK (Konferensi Nasional Teknologi Informasi Dan Komputer), 3(1), 1-8. https://doi.org/10.30865/komik.v3i1. $\underline{1688}$
Rokhib, M. A. (n.d.). Penggunaan Data Mining Untuk Pengelolaan Data Dalam Bidang Pendidikan. 1-4.

Nugraha, P. G. S. C., Aribawa, I. W., Priyana, I. P. O., \& Indrawan, G. (2016). Penerapan Metode Decision Tree(Data Mining) Untuk Memprediksi Tingkat Kelulusan Siswa Smpn1 Kintamani. Seminar Nasional Vokasi Dan Teknologi (SEMNASVOKTEK), 35-44.

http://eksis.ditpsmk.net/artikel/definisi-smksekolah-menengah-kejuruan 